\title{
$\mathrm{Rh}$ Blood Group of Grandmother and Incidence of Erythroblastosis
}

\author{
J. M. RAMOS DE ALMEIDA and LINO ROSADO \\ From Maternity Hospital Dr. Alfredo da Costa, Lisbon, Portugal
}

\begin{abstract}
Ramos de Almeida, J. M., and Rosado, L. (1972). Archives of Disease in Childhood, 47, 609. Rh blood group of grandmother and incidence of erythroblastosis. Maternal red cells may cross the placental barrier and enter the fetal circulation, and this transfer may cause primary sensitization in $\mathrm{Rh}$-negative girls born to $\mathrm{Rh}$-positive mothers.

60 families were studied. Each family consisted of the grandmother, her Rhnegative daughter, and the Rh-positive grandchildren. Only families with ABO compatibility in the three generations, and where the mothers had never been transfused or had never received blood intramuscularly, were selected.

The families were divided into 2 groups: the group of the $\mathrm{Rh}$-positive grandmothers, group $(+)$, which consisted of 40 families, and the group of Rh-negative grandmothers, group (-), which consisted of 20 families.

The 2 groups were analysed as to the presence of affected grandchildren in any pregnancy. There were $35(87.5 \%)$ affected grandchildren in group $(+)$, and 15 $(75 \%)$ affected children in group (-).

In group $(+)$ the number of mothers with 3 or more $\mathrm{Rh}$-positive pregnancies was 16 , and of these, $4(25 \%)$ had only unaffected children. In group (-) 15 mothers had 3 or more Rh-positive pregnancies, and of these, $4(27 \%)$ had only unaffected children.

There was a striking similarity in the percentage of affected children between the 1 st birth in group $(+), 20 \%$, and the 2 nd birth in group (-), $20 \%$; the 2 nd birth in group $(+), 38 \%$, and the 3rd birth in group (-), 30\%; the 3rd birth in group $(+)$, $28 \%$, and the 4 th birth in group (-), $25 \%$.

It was concluded that (1) an Rh-positive grandmother acts similarly to the antigenic stimulation caused by pregnancy and the birth of an $\mathrm{Rh}$-positive fetus; (2) it might be advisable to inject all Rh-negative newborn females, born to Rh-positive mothers, with anti-D $\gamma$-globulin, soon after birth; (3) prediction of the risk of erythroblastosis, especially in the case of primigravidae or mothers with one nonaffected Rh-positive child, requires the investigation of the blood group of the grandmother on the mother's side.
\end{abstract}

Every woman who has had one or more pregnancies has been in physiological connexion with an alien circulation through the placenta $(x+1)$ times, $x$ being the number of her own pregnancies, and 1 her own gestation, when she was connected to the maternal circulation while in her mother's uterus (Fig.). In both instances the two circulations may not be completely separated from one another. During pregnancy, and especially after delivery, fetal red cells frequently are to be found

Received 17 December 1971. in the maternal circulation (Woodrow and Donohoe, 1968). This transfer of cells can also occur in the opposite direction, maternal red cells being found in the fetal circulation (Zarou, Lichtman, and Hellman, 1964).

Since the stimulus to $\mathrm{Rh}$ immunization is the introduction of $\mathrm{Rh}$-positive erythrocytes into an $\mathrm{Rh}$-negative recipient, haemolytic disease due to $\mathrm{Rh}$ incompatibility occurs whenever an Rh-negative woman has become sensitized to the antigens present in the transfused red cells which she may have acquired, either from her own mother during 


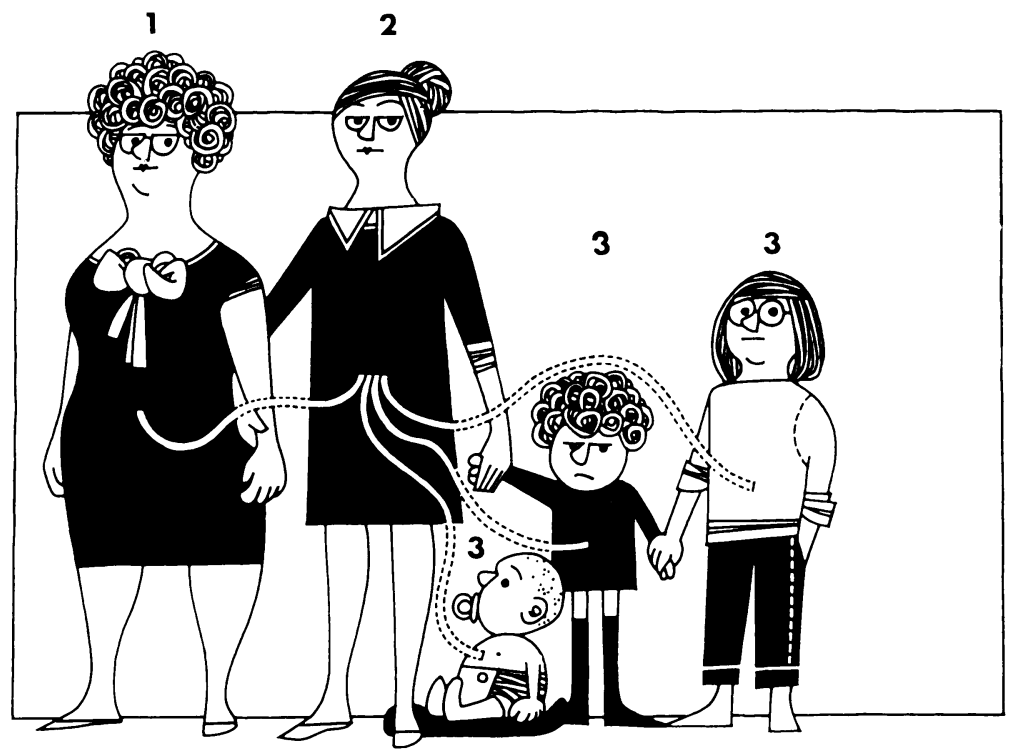

FIG.-Erythroblastotic saga. A mother may be immunized by receiving blood transferred across the placenta from her own $\stackrel{\bullet}{\complement}$ mother, as well as from her own offspring. 'On the side of the mother-in-law there is reluctance to give up the possession $\stackrel{\varrho}{+}$ of her daughter, distrust of the stranger to whom she is to be handed over, an impulse to retain the dominating position which $\vec{\omega}$ she has occupied in her own house.' Sigmund Freud, Totem and Taboo.

gestation and at birth, or later on from her fetuses during her own pregnancies. In the first of these two situations this transfer of maternal cells into the fetal circulation may theoretically cause primary sensitization in an Rh-negative girl born to an $\mathrm{Rh}$-positive mother.

This investigation was aimed at determining the influence of a grandmother's $\mathrm{Rh}$ blood group on her Rh-positive grandchildren, by studying (1) the incidence of erythroblastosis, and (2) the birth order of the first affected child.

\section{Clinical Material}

Sixty families were studied. Each family consisted of the grandmother, her $\mathrm{Rh}$-negative daughter, and the $\mathrm{Rh}$-positive grandchildren. So 60 nonrelated grandmothers, their $60 \mathrm{Rh}$-negative daughters, and their $\mathrm{Rh}$-positive children were studied. Since, in the presence of $\mathrm{ABO}$ incompatibility, transfused red cells are destroyed before they can stimulate the production of $\mathrm{Rh}$ antibodies, only families with $\mathrm{ABO}$ compatibility in the three generations were selected. The families were all either $\mathrm{A}$ or $\mathrm{O}, 27$ families being $\mathrm{A}$ and 33 families being $\mathrm{O}$.

Furthermore, only families with mothers who had declared they had never had a miscarriage, nor had been transfused or injected intramuscularly with blood, were selected. The 60 families were divided into 2 groups: the group of $\mathrm{Rh}$-positive grandmothers, group $(+)$, which consisted of 40 families, and the group of
Rh-negative grandmothers, group (-), which consisted of 20 families.

In group $(+)$ there were $6 \mathrm{Rh}$-negative grandchildren, and in group (-) there were 4 . These pregnancies $\frac{O}{\mathbb{D}}$ and these children were not taken into account for our $\mathrm{Q}$ data. The diagnosis of erythroblastosis was based on $\overrightarrow{\overline{0}}$ clinical evidence, on the presence of antibodies in the 3 mother's serum, and on a positive antiglobulin test in the infant's cells.

\section{Results}

The analysis of the 2 groups as to the presence ? of affected grandchildren in any pregnancy is $\bar{O}$ shown in Table I. There is no significant difference between the 2 groups $\left(\chi^{2}=0 \cdot 39\right)$.

TABLE I

Number of Mothers in Two Groups Who Have Had Any Erythroblastotic Children

\begin{tabular}{l|c|c}
\hline & $\begin{array}{c}\text { No. in } \\
\text { Group }\end{array}$ & $\begin{array}{c}\text { No. with Erythro- } \\
\text { blastotic children }\end{array}$ \\
\hline $\begin{array}{l}\text { Rh-positive grandmothers } \\
\text { (Group (+)) } \\
\begin{array}{l}\text { Rh-negative grandmothers } \\
(\text { Group }(-))\end{array}\end{array}$ & 40 & $35(87 \cdot 5 \%)$ \\
\hline Total & 60 & 50 \\
\hline
\end{tabular}

Table II shows the number of mothers in each $\overrightarrow{\mathbb{D}}$ group with 3 or more Rh-positive, ABO compatible 
pregnancies, and of these, the numbers who had any affected children and who had only unaffected children.

In Table III the 2 groups are compared as to the birth order of the first affected sib.

\section{TABLE II}

Number of Mothers with 3 or More Rh-positive, ABO Compatible Pregnancies

\begin{tabular}{|c|c|c|c|}
\hline $\begin{array}{l}\text { Rh-positive } \\
\text { grandmothers } \\
\text { (40) } \\
\text { (Group }(+))\end{array}$ & $16(40 \%)$ & $\begin{array}{l}\text { Mothers with } \\
\text { affected } \\
\text { children } \\
\text { Mothers with } \\
\text { no affected } \\
\text { children }\end{array}$ & $4(25 \%)$ \\
\hline $\begin{array}{l}\text { Rh-negative } \\
\text { grandmothers } \\
\text { (20) } \\
\text { (Group (-)) }\end{array}$ & $15(75 \%)$ & $\begin{array}{l}\text { Mothers with } \\
\text { affected } \\
\text { children } \\
\text { Mothers with } \\
\text { no affected } \\
\text { children }\end{array}$ & $\begin{array}{l}11 \\
4(26 \cdot 6 \%)\end{array}$ \\
\hline
\end{tabular}

Note: In both groups, 1 mother had 2 pregnancies of unaffected Rh-positive children.

TABLE III

Birth Order of First Affected Child

\begin{tabular}{l|c|c|c|c}
\hline Birth Order & 1 & 2 & 3 & 4 \\
\hline $\begin{array}{l}\text { Rh-positive } \\
\text { grandmothers } \\
\text { (Group }(+))\end{array}$ & $8(20 \%)$ & $15(37 \cdot 5 \%)$ & $11(27 \cdot 5 \%)$ & 1 \\
$\begin{array}{l}\text { Rh-negative } \\
\text { grandmothers } \\
\text { (Group (-)) }\end{array}$ & 0 & $4(20 \%)$ & $6(30 \%)$ & $5(25 \%)$ \\
\hline
\end{tabular}

\section{Discussion}

The data in Table I show a very large percentage of affected children compared to the usual figures. While the possibility of undeclared previous pregnancies cannot be ruled out, probably a more important fact is that our series included only families with $\mathrm{ABO}$ compatibility between children and their mothers.

The data also show that $\mathrm{Rh}$-positive grandmothers do not cause in their families an excessive number of grandchildren affected by erythroblastosis. This is in conflict with Taylor's (1967) results which showed an increased number of mothers with affected children in families with Rh-positive grandmothers. The explanation may be that in our series $83 \%$ of the mothers went on having children until they had an affected child. In fact, at the time the data were collected the average number of children per family was 2.5 in group $(+)$ and $3 \cdot 2$ in group $(-)$.
This is also shown in Table II. In group (-) the percentage of mothers with 3 or more Rhpositive, $A B O$ compatible pregnancies was significantly larger than in group $(t)$.

Since 3 is the number of stimulations by pregnancy required for the majority of women who have affected children (Taylor, 1967), we studied the percentage of mothers with 3 or more unaffected Rh-positive children. The percentages in the 2 groups were similar (Table II). Probably these mothers (in both groups) belonged to the type of $\mathrm{Rh}$-negative persons who, though receiving $\mathrm{Rh}$ positive blood, never produce antibodies (Allen and Diamond, 1958).

In Table III the very striking similarity in the percentage of affected children between the 1st birth in group $(+)$ and the 2 nd in group ( -$)$, the 2nd birth in group $(+)$ and the 3 rd in group (-), the 3rd birth in group (+) and the 4th in group (-), suggests that an Rh-positive grandmother acts similarly to the antigenic stimulation caused by pregnancy and the birth of an $\mathrm{Rh}$-positive fetus.

\section{Conclusion}

It is often said that pregnancy alone usually leads to no significant transfer of red cells from the fetus into the mother, and that delivery is the main cause of important transplacental haemorrhage, so that immunization rarely develops in the course of a first pregnancy.

Our results suggest that primary $\mathrm{Rh}$-immunization may precede the first pregnancy, due to maternofetal transfer of $\mathrm{Rh}$-positive red cells during the birth of an $\mathrm{Rh}$-negative girl to an $\mathrm{Rh}$ positive mother.

If maternofetal transfer of cells takes place mainly during delivery, as is the case in fetomaternal transfer of cells, it would perhaps be advisable to inject with anti-D $\gamma$-globulin soon after birth all $\mathrm{Rh}$-negative newborn females born to $\mathrm{Rh}$-positive mothers.

Finally, for proper prediction of the risk of sensitization in an Rh-negative woman, especially in the case of primigravidae or mothers of a first $\mathrm{Rh}$-positive child, the $\mathrm{Rh}$ blood group of the grandmother on the mother's side should always be investigated. Engaged couples should inquire about each other's blood group, and the man should always question his fiancée as to her mother's blood group. The combination of an Rh-positive motherin-law with a homozygotic $\mathrm{Rh}$-positive son-in-law is particularly hazardous.

We thank Mr. J. Abel Manta for drawing the Figure. 
REFERENCES

Allen, F. H., Jr., and Diamond, L. K. (1958). Erythroblastosis Fetalis. Little, Brown, Boston; Churchill, London.

Freud, S. (1955). The Standard Edition of the Complete Psychological Works of Sigmund Freud, Vol. XIII, Totem and Taboo and other Works, p. 14. Hogarth, London.

Taylor, J. F. (1967). Sensitization of Rh-negative daughters by their Rh-positive mothers. New England fournal of Medicine, 276, 547.
Woodrow, J. C., and Donohoe, W. T. A. (1968). Rh-immunization by pregnancy: results of a survey and their relevance to prophylactic therapy. British Medical fournal, 4, 139.

Zarou, D. M., Lichtman, H. C., and Hellman, L. M. (1964). The transmission of chromium-51 tagged maternal erythrocytes $\mathscr{N}$ from mother to fetus. American fournal of Obstetrics and Gynecology, 88, 565.

Correspondence to Dr. J. M. Ramos de Almeida, Av. Miguel Bombarda, $8.7^{\circ}$, Lisbon, Portugal.

The following articles will appear in future issues of this journal:

Review Article: Regulation of Erythropoiesis in the Fetus and Newborn. By P. H. Finne and S. Halvorsen. Leucocyte Blood Picture in Ill Newborn Babies. By M. Xanthou.

Confidential Inquiry into 226 Consecutive Infant Deaths. By I. D. G. Richards and H. T. McIntosh.

Personal Practice: Treatment of Acute Lymphoblastic Leukaemia. By L. F. Sinks.

Clicks, Whoops, and Honks. By D. Pickering.

Duodenal Ulcer in Children. By J. D. A. Robb, P. S. Thomas, J. Orszulok, and G. W. Odling-Smee.

Pycnodysostosis: A Variant Form with Visceral Manifestations. By K. Kozlowski and J. S. Yu.

Australia Antigen and Antibody in Transfused Children with Thalassaemia. By A. Vierucci, W. T. London, B. S. Blumberg, A. I. Sutnick, and F. Ragazzini.

Histiocytoma Presenting as Swelling on the Toe. By D. Spencer and J. D. Wrighton.

Spinal Cord Compression as a Complication of Haemophilia. By M. L. Keeley, N. Taylor, and R. L. Chard, Jr. Lung Mechanics in Normal Infants and Infants with Congenital Heart Disease. By G. Howlett.

Controlled Measures of Exploratory Movement in a Coeliac Child During Gluten Withdrawal. By D. N. Challacombe, M. J. MacCulloch, and C. J. Birtles.

Coagulation Studies in Haemolytic Uraemic Syndrome. By M. L. N. Willoughby, A. V. Murphy, S. McMorris, and F. G. Jewell.

Glycogen Storage Disease, Type VIII. By M. Ludwig, S. Wolfson, and O. Rennert. 